\title{
BNREL
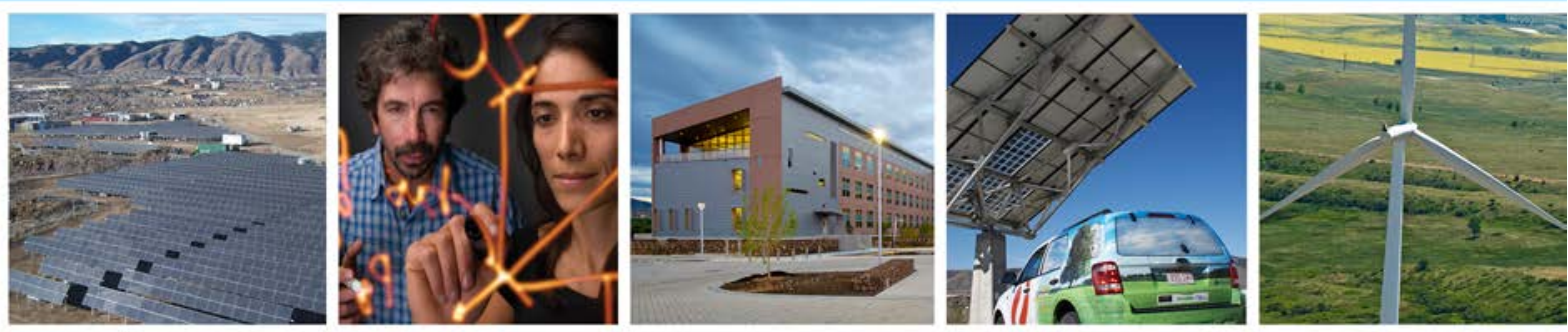

\section{Characterization of Epitaxial Film Silicon Solar Cells Grown on Seeded Display Glass}

\section{Preprint}

David L. Young, Sachit Grover, Charles Teplin, Paul Stradins, Vincenzo LaSalvia, and Howard M. Branz National Renewable Energy Laboratory

Ta-Ko Chuang and J. Greg Couillard Corning Incorporated

Presented at the 2012 IEEE Photovoltaic Specialists Conference Austin, Texas June 3-8, 2012 


\section{NOTICE}

The submitted manuscript has been offered by an employee of the Alliance for Sustainable Energy, LLC (Alliance), a contractor of the US Government under Contract No. DE-AC36-08GO28308. Accordingly, the US Government and Alliance retain a nonexclusive royalty-free license to publish or reproduce the published form of this contribution, or allow others to do so, for US Government purposes.

This report was prepared as an account of work sponsored by an agency of the United States government. Neither the United States government nor any agency thereof, nor any of their employees, makes any warranty, express or implied, or assumes any legal liability or responsibility for the accuracy, completeness, or usefulness of any information, apparatus, product, or process disclosed, or represents that its use would not infringe privately owned rights. Reference herein to any specific commercial product, process, or service by trade name, trademark, manufacturer, or otherwise does not necessarily constitute or imply its endorsement, recommendation, or favoring by the United States government or any agency thereof. The views and opinions of authors expressed herein do not necessarily state or reflect those of the United States government or any agency thereof.

Available electronically at http://www.osti.gov/bridge

Available for a processing fee to U.S. Department of Energy and its contractors, in paper, from:

U.S. Department of Energy

Office of Scientific and Technical Information

P.O. Box 62

Oak Ridge, TN 37831-0062

phone: 865.576.8401

fax: 865.576 .5728

email: mailto:reports@adonis.osti.gov

Available for sale to the public, in paper, from:

U.S. Department of Commerce

National Technical Information Service

5285 Port Royal Road

Springfield, VA 22161

phone: 800.553 .6847

fax: 703.605.6900

email: orders@ntis.fedworld.gov

online ordering: http://www.ntis.gov/help/ordermethods.aspx

Cover Photos: (left to right) PIX 16416, PIX 17423, PIX 16560, PIX 17613, PIX 17436, PIX 17721

Printed on paper containing at least $50 \%$ wastepaper, including $10 \%$ post consumer waste. 


\title{
Characterization of Epitaxial Film Silicon Solar Cells Grown on Seeded Display Glass
}

\author{
David L. Young ${ }^{1}$, Sachit Grover ${ }^{1}$, Charles Teplin ${ }^{1}$, Paul Stradins ${ }^{1}$, Vincenzo LaSalvia ${ }^{1}$, \\ Ta-Ko Chuang ${ }^{2}$, J. Greg Couillard ${ }^{2}$, Howard M. Branz ${ }^{1}$ \\ ${ }^{1}$ National Renewable Energy Laboratory, Golden, CO, USA \\ ${ }^{2}$ Corning Incorporated, Corning, NY, USA
}

\begin{abstract}
We report characterization of epitaxial film crystal silicon (c-Si) solar cells with open-circuit voltages $\left(V_{o c}\right)$ above $560 \mathrm{mV}$. The 2-um absorber cells are grown by low-temperature $\left(<750{ }^{\circ} \mathrm{C}\right)$ hot-wire CVD (HWCVD) on Corning ${ }^{\circledR}$ EAGLE XG ${ }^{\circledR}$ display glass coated with a layer-transferred (LT) Si seed. The high $V_{o c}$ is a result of low-defect epitaxial $\mathrm{Si}$ (epi-Si) growth and effective hydrogen passivation of defects. The quality of epitaxial growth by HWCVD on seeded glass substrates depends on the crystallographic quality of the seed and the morphology of the growth surface. Complete heterojunction cells consist of glass/c-Si LT seed/ epi $n^{+} \mathrm{Si}: P /$ epi $\mathrm{n}^{-} \mathrm{Si}$ :P/intrinsic a$\mathrm{Si}: \mathrm{H} / \mathbf{p}^{+}$a-Si:H/ITO. Similar devices grown on electronically 'dead' $n^{+}$wafers have given $V_{o c} \sim 630 \mathrm{mV}$ and $\sim 8 \%$ efficiency with no light trapping features. Here we study the effects of the seed surface polish on epi-Si quality, how hydrogenation influences the device character, and the dominant junction transport physics.
\end{abstract}

Index Terms - epitaxial layers, glass, silicon, solar energy.

\section{INTRODUCTION}

The commercial photovoltaic market continues to be dominated by crystalline silicon wafer technology. However, epitaxial film-silicon on seeded low-cost substrates ("epi on seed") is a viable technology that could provide reduced manufacturing costs without sacrificing efficiency. Our group is exploring growth of epitaxial films on low-cost, seeded-substrates by hot-wire CVD (HWCVD). HWCVD allows nearly defect free epitaxial growth on wafers at deposition rates $>1.8$ $\mu \mathrm{m} / \mathrm{min}$ nearly 300 to $400{ }^{\circ} \mathrm{C}$ below typical chemical vapor deposition epitaxy[1]. The lower HWCVD growth temperature allows low-cost, low-temperature substrates, such as display glass, to be used as the substrate for large area crystal film silicon solar modules. Though NREL has investigated a variety of homo- and heteroepitaxial seeds on glass substrates, this contribution will focus mainly on layer-transfer (LT) c-Si films oxide-bonded to Corning $^{\circledR}$ EAGLE XG ${ }^{\circledR}$ glass (hereafter SiOG) [2, 3]. Our study explores the influence of the surface preparation of the seed layer to obtain low-defect density epitaxial films, and compares material quality and device characterization between SiOG and wafer-based devices. Not surprisingly seed layer surface preparation greatly influences the epi-Si and device quality. We find that with a seed layer surface roughness nearly $10 x$ rougher than a wafer, we get about 10x more dislocations and a lower $\mathrm{V}_{\mathrm{oc}}$ compared to epi-Si devices grown on prime polished $\mathrm{n}^{+}$wafers. Yet, the $\mathrm{V}_{\mathrm{oc}}$ obtained in our preliminary study are the highest reported for crystal $\mathrm{Si}$ films on display glass.

\section{EXPERIMENT}

Two types of substrates are explored in this study: 1) electronically 'dead' $\mathrm{n}^{+} \mathrm{Si}: \mathrm{P}$ wafers with a prime surface polish in which photo generated carriers have minimal chance to be collected; and 2) LT c-Si films oxide-bonded to Corning ${ }^{\circledR}$ EAGLE XG ${ }^{\circledR}$ glass (SiOG).

Epitaxial films are grown on the LT seed layer by HWCVD using a gas mixture of $\mathrm{SiH}_{4}, \mathrm{H}_{2}$, and $\mathrm{PH}_{3}$ over the temperature range of $650-830{ }^{\circ} \mathrm{C}$. Emitters are formed by growing a heterojunction structure with hydrogenated amorphous $\mathrm{Si}[\mathrm{i}$ a-Si:H $(\sim 5 \mathrm{~nm}), \mathrm{p}$ a-Si:H:B $(\sim 15 \mathrm{~nm})]$ in separate HWCVD deposition chambers.

An $\mathrm{In}_{2} \mathrm{O}_{3}: \mathrm{Sn}$ film provides a transparent conducting contacting layer and an antireflective coating. Device mesas are photolithographically defined and isolated with reactive ion etching using $\mathrm{SF}_{6}$ gas. Back contacts are formed to a grown-in, heavily doped back surface field layer (Fig. 1). For epi-Si devices on 'dead' wafer, contact is made directly to the highly conducting wafer and no $\mathrm{n}+$ layer is grown. Measurements of illuminated current density vs voltage (JV) are done with a calibrated AM1.5 solar simulator to give the operating parameters for the

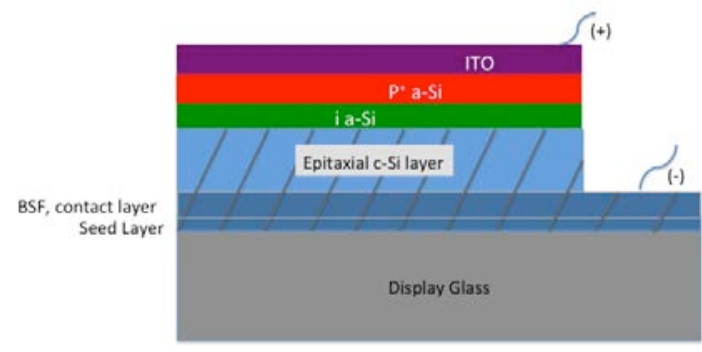

Fig. 1. Device schematic. 
solar cell. Light and dark JV measurements are made between $150 \mathrm{~K}-350 \mathrm{~K}$ with a Linkam Scientific cryostat and a Keithley 6517B electrometer. Quantum efficiency $(\mathrm{QE})$, capacitance vs voltage $(\mathrm{C} / \mathrm{V})$ measurements are made with custom equipment.

\section{SEED PREPARATION}

The LT seed layers were exfoliated from wafers following a hydrogen implant to a specified depth and annealing to form hydrogen platelets. Before the seed layer is exfoliated, the wafers are oxide-bonded to display glass. The exposed surface (cut layer) of the exfoliated seed is quite rough (see Fig. 2 (left)) with an average surface roughness of about $8 \mathrm{~nm}$, compared to $<0.1 \mathrm{~nm}$ average surface roughness of the polished wafers. Silicon on insulator (SOI) wafers formed from either smart cut technology or by porous silicon layer transfer, when used in the IC industry, are commonly heated to $1150{ }^{\circ} \mathrm{C}$ in 80 Torr hydrogen for 1 hour to dramatically reduce the surface RMS roughness to below $0.1 \mathrm{~nm}$ [4]. A similar high $\mathrm{T}$ anneal was used by Gordon et al. to smooth exfoliated seeds on spinel glass-ceramic substrates before $1130{ }^{\circ} \mathrm{C}$ epitaxial growth [5]. On SOI and glassceramic, the substrate can withstand the high annealing temperatures necessary for surface reconstruction of the
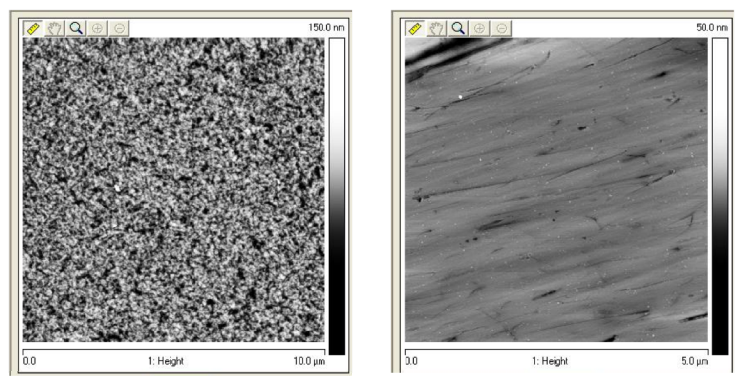

Fig. 2 AFM images of (left) as cut SiOG and (right) after CMP.

seed layer. Corning ${ }^{\circledR}$ EAGLE XG ${ }^{\circledR}$ glass, used in this study, is far less costly than the glass-ceramic, but has an annealing temperature of $722{ }^{\circ} \mathrm{C}$ and a softening point of $971{ }^{\circ} \mathrm{C}$. Even though the price point for this type of glass is low enough for use in low-cost solar modules and the working temperatures are compatible with HWCVD epitaxy, the display glass cannot sustain a hightemperature hydrogen anneal necessary for surface reconstruction. We therefore explored two lowtemperature techniques to smooth the surface of the seed layer for epitaxial growth. Our first approach was to perform a chemical/mechanical polish (CMP) on the seed, being careful not to grind away the entire $600-\mathrm{nm}$-thick as-cut seed layer. Removing about $400 \mathrm{~nm}$ of $\mathrm{c}-\mathrm{Si}$ reduced the average surface roughness to $1 \mathrm{~nm}$. However, polishing introduced groves into the surface of the seeds, as visible by AFM (Fig. 2 (right)). Our next approach was to anneal the seeds in hydrogen at $800{ }^{\circ} \mathrm{C}$ for 30 mins. This proved insufficient to improve the surface roughness of either the as-cut or polished seed layers.

\section{EPITAXIAL FILMS ON SEEDS}

Epitaxial films are grown on the polished seed layers by placing them on a vertically-oriented heater in the HWCVD epitaxial reactor and heating to just below the unsupported deformation point of the 1" $\mathrm{x} 0.45$ " glass substrate. We measure this maximum sustainable temperature to be about $775{ }^{\circ} \mathrm{C}$ by using in situ spectroscopic ellipsometry[6]. Our previous research indicated that oxide growth on the surface prior to epi-Si deposition induces dislocations in the epi film that propagate through the film to the surface [7]. We therefore start our epi-Si growth with oxygen-filtered silane. We then use a $\mathrm{SiH}_{4} / \mathrm{PH}_{3}$ mixture, without filtering, to form the $\mathrm{n}^{+} / \mathrm{n}^{-}$layers. Optical and scanning electron microscopy (SEM) images of the surface of the epi-Si films show sparse $\left(<10^{4} \mathrm{~cm}^{-2}\right)$ crystallographic pits and defect densities. Electron-beam induced current (EBIC) images on fully processed devices show active defect densities on the order of $10^{4}-10^{5} \mathrm{~cm}^{-2}$. TEM studies show these defects are predominately dislocations and twins.

\section{HYDROGENATION}

Once the $\mathrm{n}^{+} / \mathrm{n}^{-}$epitaxial films are grown, the samples are hydrogenated in a custom-built remote plasma, rapid thermal annealing system. As-grown films have about

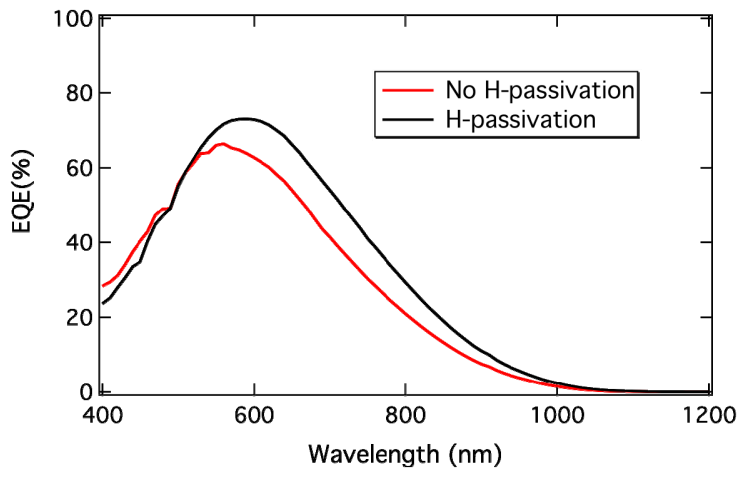

Fig. 3 External quantum efficiency with and without hydrogen passivation.

$2 \times 10^{17} \mathrm{~cm}^{-3} \mathrm{H}$ somewhat uniformly distributed throughout the film (determined by SIMS). After hydrogenation, $\mathrm{H}$ 
concentrations increase $\sim 10 \mathrm{x}$ in the top $1 \mu \mathrm{m}$ of the film and decrease to $\sim 4 \times 10^{17} \mathrm{~cm}^{-3}$ near the back of the film. Hydrogenation improves both $\mathrm{J}_{\mathrm{sc}}$ and $\mathrm{V}_{\mathrm{oc}}$. Fig. 3 shows typical EQE data for nominally identical devices on $n+$ wafers with and without hydrogenation.

The QE in the $400-550 \mathrm{~nm}$ range is almost identical before and after hydrogenation, however there is a pronounced increase in the QE for the hydrogenated sample beyond $550 \mathrm{~nm}$ out to $1000 \mathrm{~nm}$. A fit to the QE data in the IR region indicates an increase in the effective diffusion length $\left(\mathrm{L}_{\mathrm{eff}}\right)$ in the bulk with hydrogenation[8]. Minority carrier lifetimes, when measured on bare epi-Si films by resonance-coupled photoconductive decay (RCPCD), are about 10-15 ns, corroborating QEdetermined $\mathrm{L}_{\text {eff }}$ measurements of about 3-5 $\mu \mathrm{m}$. These data indicate an improvement in the bulk of the epi, but not a significant change near the surface of the epi-Si films with hydrogenation.

\section{DEVICE FABRICATION AND CHARACTERIZATION}

Following hydrogen passivation of the epi-Si layer, emitter heterojunction layers of a-Si (i) and a-Si:H $\left(\mathrm{p}^{+}\right)$ are deposited by HWCVD in a separate deposition chamber after an air break and dilute HF etch. A $70 \mathrm{~nm}$ ITO layer is then deposited by reactive evaporation of an In/Sn compound to give a contact and Anti-Reflection layer. Devices are defined by photolithography, and then a wet chemical etch is used to remove the ITO and a dry reactive ion etch (RIE) removes the $\mathrm{n}^{-}$layer down to the $\mathrm{n}^{+}$back contact layer (see Fig. 1). This $\mathrm{n}^{+}$layer is

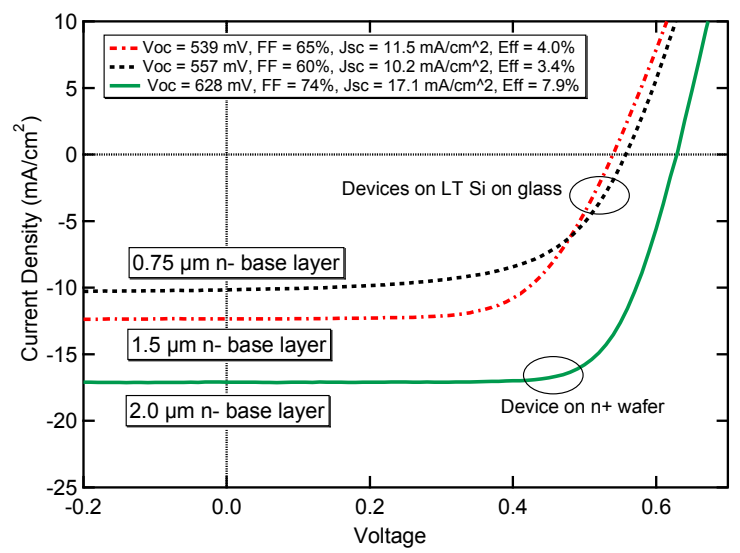

Fig. 4 Current density vs voltage for several devices described in the text.

necessarily thick $(\sim 2 \mu \mathrm{m})$ to provide a large RIE process window in order to stop the RIE etch within the $\mathrm{n}^{+}$layer. A thicker $\mathrm{n}+$ layer provides more lateral conduction to the back contact and thus a lower $\mathrm{R}_{\text {series}}$, but it also introduces a larger 'dead' layer in the device that absorbs light without providing carriers that contribute to the current. Fig. 4 shows typical JV curves for heterojunction devices on glass substrates and on a 'dead' $\mathrm{n}+$ wafer.

The relatively high open circuit voltages $(630 \mathrm{mV}$ for $\mathrm{n}^{+}$'dead' wafer devices and $560 \mathrm{mV}$ for SiOG devices) indicate high quality material $\left(\mathrm{L}_{\mathrm{eff}} / \mathrm{W}>3\right)$ and junction formation, whereas the low fill factors show that our $\mathrm{R}_{\text {series }}$ remains too high despite the thick $\mathrm{n}^{+}$layer. $\mathrm{R}_{\text {series }}$ is much larger in the SiOG devices compared with the wafer devices (Fig. 4) due to inadequate $\mathrm{n}+$ doping in the back contact layer, which contributes to the lower FF. However, the lower $\mathrm{V}_{\text {oc }}$ values for SiOG devices are a result of shorter diffusion lengths and a defective junction surface due to a higher dislocation density in the SiOG epi-Si layers. These dislocations may act to shunt the

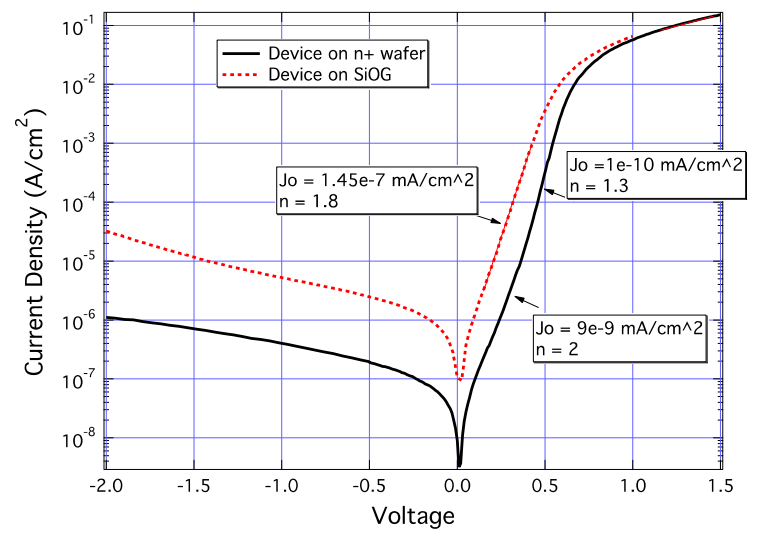

Fig. 5 Dark current density vs voltage data for $\mathrm{SiOG}$ device and device on $\mathrm{n}^{+}$wafer.

device and/or introduce recombination centers within the depletion region [9]. Both of these effects result in a higher dark saturation current density (Fig. 5), higher

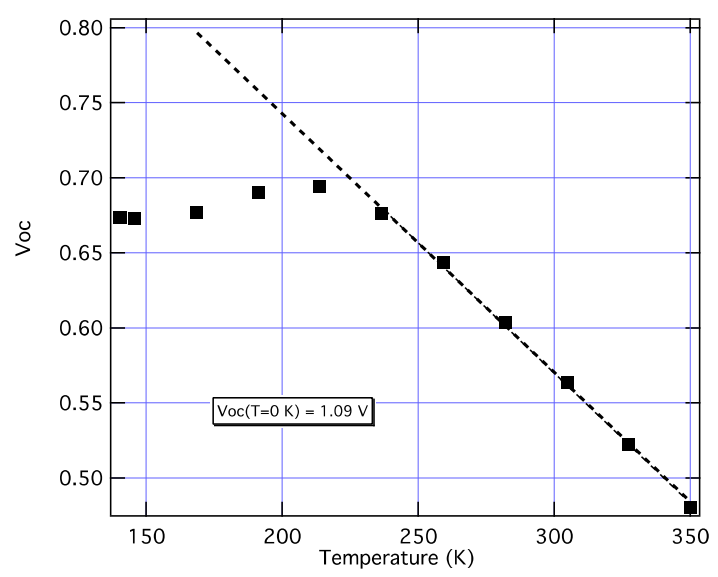

Fig. 6 Temperature corrected Voc vs Temperature data for a device on SiOG. 
ideality factors near $\mathrm{V}_{\mathrm{oc}}$ (Fig. 5) and higher surface recombination velocities $\left(\mathrm{S}_{\mathrm{p}}\right)$ at the heterojunction interface (see below) in $\mathrm{SiOG}$ devices compared with wafer based devices. The dark JV data of Fig. 5 reveal that our devices on $n+$ wafers show the typical voltage dependence in forward bias as high efficiency waferbased heterojunction devices[10]. However, our SiOG devices show forward bias JV(Temperature) characteristics typical of surface dominated recombination. To verify this, Fig. 6 shows $V_{o c}$ vs Temperature data for a SiOG device. The temperaturecorrected $\mathrm{V}_{\mathrm{oc}}$ at $\mathrm{T}=0 \mathrm{~K}$ is less than the bandgap of silicon, indicating interface recombination likely dominates junction transport[11]. Combining $\mathrm{V}_{\mathrm{oc}}$ vs $\mathrm{J}_{\mathrm{sc}}$ data with a built-in potential value measured by capacitance vs voltage data (not shown), we find front surface interface recombination velocities much higher in SiOG devices, compared with low-defect density wafer based devices confirming that surface recombination dominates in SiOG devices.

These preliminary results on high $\mathrm{V}_{\mathrm{oc}}$ SiOG devices are encouraging for this technology. However, much work is needed to reduce defects to increase both the bulk and surface quality in these devices.

The authors thank Lorenzo Roybal, for growth of the ITO films, and Russell Bauer, for the hydrogenation of the epi-Si films.

\section{REFERENCES}

[1] Bobela, D.C., C.W. Teplin, D.L. Young, H.M. Branz, and P. Stradins. "epitaxial crystal silicon absrober layers and solar cells grown at 1.8 microns per minute", in IEEE-PVSC. 2011. Seattle WA: IEEE.

[2] Groves, J.R., J.B. Li, B.M. Clemens, V. Lasalvia, F. Hasoon, H.M. Branz, and C.W. Teplin, "Biacially-textured photovoltaic film crystal silicon on ion beam assisted deposition CaF2 Seed layers on glass". Energy and Environmental Science, submitted 2012

[3] Young, D.L., K. Alberi, C. Teplin, I. Martin, P. Stradins, M. Shub, C. Beall, E. Iwaniczko, H. Guthrey, M.J. Romero, T.-K. Chuang, E. Mozdy, and H.M. Branz, "Toward film-silicon solar cells on display glass", in IEEE PVSC 35, IEEE, Editor. 2010, IEEE: Honolulu Hawaii. p. 626-630.

[4] Sato, N. and T. Yonehara, "Hydrogen Annealed silicon-oninsulator". Applied Physics Letters, 65(15) 1994, p. 1924.

[5] Gordon, I., S. Vallon, A. Mayolet, G. Beaucarne, and J. Poortmans, "Thin-Film Monocrystalline-silicon solar cells made by a seed layer approach on glass-ceramic substrates". Solar Energy Materials \& Solar Cells, 94 2010, p. 381.

[6] Teplin, C.W., D. Levi, E. Iwaniczko, K.M. Jones, J. Perkins, and H.M. Branz, "Monitoring and modeling silicon homoepitaxy breakdown with real-time spectroscopic ellipsometry". J. Applied Physics, 972005

[7] Teplin, C.W., K. Alberi, M. Shub, C. Beall, I.T. Martin, M.J. Romero, D.L. Young, R.C. Reedy, P. Stradins, and H.M. Branz,
"Mechanisms controlling the phase and dislocation density in epitaxial silicon films grown from silane below $800^{\circ} \mathrm{C}^{\prime \prime}$. APL, 96 2010, p. 201901.

[8] Basore, P.A., "Numerical Modeling of Textured Silicon Solar Cells Using PC-1D". IEEE Transactions on electron devices, 37(2) 1990

[9] Romero, M.J., K. Alberi, I.T. Martin, K.M. Jones, D.L. Young, Y. Yan, C. Teplin, M.M. Al-Jassim, P. Stradins, and H.M. Branz, "Nanoscale measurements of local junction breakdown in epitaxial film silicon solar cells". Applied Physics Letters, 97 2010, p. 092107.

[10] Young, D.L., J.V. Li, C.W. Teplin, P. Stradins, and H.M. Branz. "Junction Transport in epitaxial film silicon heterojunction solar cells". in IEEE PVSC. 2011. Seattle: IEEE.

[11] Rau, U. and H.W. Schock, "Electronic Properties of $\mathrm{Cu}(\mathrm{In}, \mathrm{Ga}) \mathrm{Se} 2$ heterojunction solar cells-recent achievements, current understanding, and future challenges". Applied Physics A, 69 1999, p. 131. 